\title{
Image Instrument Construct Validation of University Institutions
}

\author{
Omar A. Flores Laguna, Karla S. Basurto Gutiérrez \\ University of Montemorelos, Mexico \\ Karla L. Haro-Zea \\ Meritorious Autonomous University of Puebla, Mexico
}

\begin{abstract}
The main purpose of this study was to determine the validation of construct and reliability of the image instrument in educational institutions. A non-random sample selection of 314 high school students from Montemorelos, Nuevo León was made. An instrument with 25 statements was created to measure the image of The University of Montemorelos (reliability $\alpha=0.956$ ). The methodologies that were utilized in the validation were factorial analysis and confirmatory analysis, with the latter made with structural equations. In the factorial analysis, it was observed that the statements were grouped into four dimensions, as it was initially planned. With the exception of one item, all the other statements were grouped in the proposed dimension. In the confirmatory validation utilizing structural equations, all the selected criteria were fulfilled.
\end{abstract}

Keywords: image, survey validation, educational institutions, students, construct validation, confirmatory validation, factorial analysis

\section{Introduction}

It is said that first impressions are never forgotten, could this be the same with educational institutions? Could knowing the perception of image be important for its development? Pintado Pasapera (2015) stated that institutional image comprehends the ensemble of communicative actions that an institution must perform in order to express their identity and sell a positive reputation. He added that the image is one of the most important factors that determine the stance towards the product and with products that cannot differentiate from the competition easily; image is the only factor that influences the stance one has towards it.

Guerra and de Arends (2008) stated that a university's institutional image is the sum of definitions the university is known for as well as how the community describes, remembers and relates to them. Universities are giving attention to their image with the purpose of being better and differentiating themselves from the competition. The image of a university is not absolute; it is relative to the image that is transmitted by other higher education institutions. For Chaves (2010), institutional image has to do with the institution's identity, how they integrate and operate in society, since this is the way the community perceives them.

Without doubt as it is stressed by Baptista Rodrigues (2012), institutions are facing an unprecedented change and image is the aspect that deserves the most attention due to how it will help them understand different communities.

Omar A. Flores Laguna, Director of the Research Department for Business, Facultad de Ciencias Empresariales y Juridicas, University of Montemorelos. Email: oflores@um.edu.mx.

Karla S. Basurto Gutiérrez, Graduated Professor, Facultad de Ciencias Empresariales y Juridicas, University of Montemorelos. Karla L. Haro-Zea, Fulltime Research Professor, Facultad de Contaduría Pública, Meritorious Autonomous University of Puebla. 
Today, it is expected that universities answer to the paradigms in education by being leaders in technological innovation as well as development of better relationships with both the state and private enterprises (Etzkowitz, Webster, Gebhardt, \& Terra, 2000). For universities to know their audience, it is important to do image research with the objective to improve relevant aspects in the different audiences' perception. Due to this, it is crucial that every instrument that is utilized for the data collection should be in compliance with the essential requirements of validation (level of degree that an instrument measures the variable it is designed to measure) and reliability (level of degree in which an instrument obtains precise results).

This study was performed with high school seniors from the most important institutions in Montemorelos, Nuevo León. Currently in Montemorelos, Nuevo León 11 high schools and four universities exist. For this study, the validation was created according to the image perception of the University of Montemorelos (UM).

The purpose of this study is the creation of an instrument to measure the image of the universities with the intent that other institutions can use it to determine the perceptions of the different audiences.

\section{Contribution and Benefits of the Study}

This study will benefit the universities that wish to study the image perception that the different audiences (students, parents, teachers, community, enterprises, etc.) have towards said institutions. Kotler and Fox (1995) stated that people form images of higher education institutions and this affects the probability of enrollment and recommending said institution.

This study is based on the impact the university has over different audiences, and if the audiences' expectations are not met, the necessary programs to meet the communities', parents', students', governments' and enterprises' expectations will be created.

The organization of this study is the following: first, a literary revision in which considered factors of the image study and other studies made are presented. In the following section, the method, sample population, description of the instrument pending validation, results of the construct validation utilizing factorial analysis and confirmatory validation by structural equations, were desctibed. In the conclusion, a summary of the instrument's validation, the validated instrument, limitations and future recommendations for other studies were given.

\section{Theoretical Framework}

For this study, it is important to know the factors that other authors have utilized to study the changing image of educational institutions to locate trends that are used in the measurement of this variable.

\section{Factors to be Considered in the Image of Universities}

Arranz Valles (2003) stated that the image of an organization has a complex number of factors that are related with culture, strategy and the competitiveness of the company. A very common error in a company's image is not taking seriously the subject of identity, as this goes further than just the logo.

Sanz de la Tajada (2003) said that the attributes of image need to identify a list of criteria for the company. It is needed to establish a methodological process that is able to extract the elements of sociocultural structure of the company.

Guerra and de Arends (2008) stated that image is related to satisfaction, expectations and perceptions of the quality of the service, organizational climate and others. Image meets in a construct of perceptions and valuations that a person decides to associate to a reality. 
Romero (2007) mentioned some strong aspects of image in universities, like an academic innovative offer, modern and bold image, modern architecture, and a firm disposition towards the transfer of knowledge and institutional collaboration. Other strong aspects are, relying with a number of aid programs, scientific output and, by those means, incorporate the alumni to the labor market.

White (1971) remarked that the young need to receive teachings from experimented teachers, for which they need to be well-read and hard-working.

Costs constitute an important aspect in the image of a university. White (1975) stated that the amount that is charged in schools for the concept of teaching and living quarters needs to be enough for the salaries of the employees, maintenance of property and buildings, and other expenses.

The Academic Vice-Rectorate of the University of Montemorelos (2013) describes in its institution objectives the following aspects as important in order to project a good image: (1) wholesome education; (2) professional competences; and (3) research and innovation.

\section{Studies About Educational Institutions’ Image}

Guerra and de Arends (2008), in an image study, recommended the following five dimensions: (1) academic quality; (2) social aspects; (3) tangible elements; (4) quality of service; and (5) accessibility.

F. Meza and R. Meza (2007) made an instrument in which the following factors that need to be taken into account to measure the image of Adventist universities. The evaluated aspects were: religious fervor, Christian philosophy, moral principles, conservative line, Goodness, cheerful spirit, practical education, innovative teachers, academic quality, management leadership, requirement of lesson plans focused on the student, campus security, community prestige, democratic management, relationship with the community, cost affordability, economic strength, campus size, campus cleanliness, modern facilities, and educational technology.

\section{Methodology}

In this section, the population, the extracted sample and the instrument are described.

\section{Population and Sample}

The National Institute of Science and Geography (2011) stated that, in Montemorelos, Nuevo León, there are 11 high school institutions, some of the most important are: (1) Academia de Ciencias Computacionales; (2) Instituto de Desarrollo Academico Profesional (Interline); (3) La Preparatoria de la Universidad de Montemorelos; (4) Preparatoria 6 de la Universidad Autónoma de Nuevo León, Tecnológico Sierra Madre (high school); and (5) Centro de Estudios Técnicos Industriales y de Servicios (CETIS 163). To perform this study, a non-random sample of 314 students of the high schools in Montemorelos was taken; these represent approximately $60 \%$ of the population. The sample consisted of 191 students from CETIS, 34 from Interline, 68 from La Preparatoria de la Universidad de Montemorelos and 21 students from the community that do not study in the mentioned institutions.

\section{The Instrument}

The instrument consists of 26 statements; however, for the validation, 25 statements were used, due to statement 26 being a question about the perceived image in a broad manner; said indicator will be used in following statistical analysis. This instrument was based up on Dr. Ramón Meza's work, instrument that had 30 statements. 
The 25 statements were grouped according to the theoretical content of each of the four dimensions, which are the following: (1) spiritual (five statements: E1-E5); (2) academic (nine statements: A6-A14); (3) social (seven statements: S15-S21); and (4) physical (four statements: F22-F25).

These statements help to know the opinion of the students, who expressed themselves regarding each statement, using the following scale: $1=$ Poor; $2=$ Bad; $3=$ Regular; $4=$ Good; and $5=$ Excellent.

According to Hair, Anderson, Tatham, and Black (2007), it is suggested to have at least five surveys per item; the ratio that was used is of almost 13 surveys per indicator, obtaining a total of 314 surveys in total. The resulting information was captured in a database, in which the pertinent statistical tests were made, using the statistical software SPSS for Windows (Version 22.0).

The data obtained in the pilot run were submitted to a factorial analysis to observe the behavior of the items and their weight in each factor.

\section{Results}

Firstly, the descriptive statistics are pointed out (see Table 1), answer alternates to 314 surveys. The lowest average is statement S22 (cost-effectiveness). The highest arithmetic mean is for statements A8 (academic quality) and S19 (campus security).

Table 1

Descriptive Statistics of the Scale's Items

\begin{tabular}{|c|c|c|}
\hline Item & $\mathrm{M}$ & $\mathrm{s}$ \\
\hline E1 & 3.74 & 1.06 \\
\hline E2 & 3.61 & 1.13 \\
\hline E3 & 3.95 & 1.06 \\
\hline E4 & 3.79 & 1.05 \\
\hline E5 & 3.81 & 1.16 \\
\hline A6 & 3.93 & 0.89 \\
\hline A7 & 3.89 & 0.98 \\
\hline A8 & 4.03 & 0.91 \\
\hline A9 & 3.98 & 0.91 \\
\hline A10 & 3.72 & 1.00 \\
\hline A11 & 3.76 & 0.98 \\
\hline A12 & 3.99 & 0.95 \\
\hline A13 & 3.89 & 0.92 \\
\hline A14 & 3.95 & 1.03 \\
\hline S15 & 3.77 & 1.00 \\
\hline S16 & 3.78 & 0.99 \\
\hline S17 & 3.91 & 0.99 \\
\hline S18 & 3.96 & 0.94 \\
\hline S19 & 4.01 & 1.01 \\
\hline S20 & 3.88 & 1.03 \\
\hline S21 & 3.81 & 1.03 \\
\hline F22 & 2.87 & 1.31 \\
\hline F23 & 3.90 & 1.06 \\
\hline F24 & 3.95 & 1.06 \\
\hline F25 & 3.65 & 1.21 \\
\hline
\end{tabular}


Factorial analysis was utilized to determine the validation of the construct (KMO $=0.936$, Bartlett's sphericity coefficient, $p<0.001$ ). The main components method was utilized as well as a varimax orthogonal rotation to clearly identify the factors with the corresponding statements. The instrument was restricted to the four dimensions that were presented by the instrument's author. The total variance explained with the four factors is of $69 \%$. Table 2 presents the MSA (sample sufficiency) and commonality (comparative variance) corresponding to each statement. Hair et al. (2007) stressed that a MSA greater than 0.80 is acceptable. It is observed that the MSA of the majority of the variables (except E1, E2, F22, and F25) are prominent, due to them being greater than 0.90 and F22 presents the lowest commonality (0.483); despite this, commonality is very close to 0.500 , reason to why it is decided that this item is to be kept in the study.

Table 2

MSA and Commonality of the 25 Statements

\begin{tabular}{lll}
\hline Item & $\mathrm{M}$ & $\mathrm{s}$ \\
\hline E1 & 0.867 & 0.780 \\
E2 & 0.837 & 0.779 \\
E3 & 0.930 & 0.678 \\
E4 & 0.904 & 0.669 \\
E5 & 0.924 & 0.634 \\
A6 & 0.938 & 0.672 \\
A7 & 0.951 & 0.780 \\
A8 & 0.958 & 0.755 \\
A9 & 0.963 & 0.640 \\
A10 & 0.948 & 0.635 \\
A11 & 0.948 & 0.635 \\
A12 & 0.959 & 0.730 \\
A13 & 0.949 & 0.698 \\
A14 & 0.943 & 0.725 \\
S15 & 0.964 & 0.732 \\
S16 & 0.950 & 0.640 \\
S17 & 0.921 & 0.670 \\
S18 & 0.928 & 0.760 \\
S19 & 0.950 & 0.743 \\
S20 & 0.958 & 0.683 \\
S21 & 0.959 & 0.652 \\
F22 & 0.887 & 0.483 \\
F23 & 0.917 & 0.694 \\
F24 & 0.937 & 0.668 \\
F25 & 0.894 & 0.719 \\
\hline
\end{tabular}

Table 3 shows the factors with their factorial loads corresponding to each of the associated statements. According to obtained results in the grouping of items with their factorial load, it can be noted that the 25 statements were grouped into four different factors as how it was initially proposed. In the academic factor, nine statements remained; social factor, the seven proposed statements remained; in the spiritual factor, only four of the five statements remained; the physical factor, the four proposed statements remained. Although item E5 (Goodness) which loads the physical factor, has been decided to left in the spiritual factor, due to it having an important factorial load in this factor. 
Table 3

Distribution of Statements After an Orthogonal Rotation

\begin{tabular}{|c|c|c|c|c|}
\hline Item & I & II & III & IV \\
\hline A12 & 0.761 & 0.282 & 0.195 & 0.184 \\
\hline A13 & 0.755 & 0.315 & 0.098 & 0.136 \\
\hline A14 & 0.738 & 0.295 & -0.050 & 0.302 \\
\hline A7 & 0.737 & 0.127 & 0.247 & 0.400 \\
\hline A8 & 0.719 & 0.301 & 0.289 & 0.253 \\
\hline A6 & 0.681 & 0.133 & 0.296 & 0.321 \\
\hline A11 & 0.672 & 0.343 & 0.196 & 0.162 \\
\hline A 10 & 0.662 & 0.319 & 0.300 & 0.074 \\
\hline A9 & 0.568 & 0.380 & 0.296 & 0.294 \\
\hline S19 & 0.144 & 0.777 & 0.215 & 0.270 \\
\hline S18 & 0.342 & 0.764 & 0.189 & 0.154 \\
\hline S20 & 0.341 & 0.694 & 0.223 & 0.189 \\
\hline S15 & 0.378 & 0.672 & 0.245 & 0.277 \\
\hline S17 & 0.354 & 0.611 & 0.118 & 0.398 \\
\hline S16 & 0.356 & 0.608 & 0.363 & 0.109 \\
\hline S21 & 0.438 & 0.602 & 0.164 & 0.268 \\
\hline E2 & 0.165 & 0.188 & 0.844 & -0.068 \\
\hline E1 & 0.178 & 0.255 & 0.825 & 0.052 \\
\hline E4 & 0.248 & 0.134 & 0.695 & 0.326 \\
\hline E3 & 0.206 & 0.256 & 0.679 & 0.328 \\
\hline F25 & 0.384 & 0.188 & -0.010 & 0.732 \\
\hline F23 & 0.235 & 0.362 & 0.142 & 0.698 \\
\hline F22 & 0.166 & 0.111 & 0.023 & 0.665 \\
\hline F24 & 0.173 & 0.351 & 0.318 & 0.643 \\
\hline E5 & 0.233 & 0.204 & 0.429 & 0.595 \\
\hline
\end{tabular}

\section{Reliability of the Instrument}

The reliability analysis was made using the original complete scale for base, as well as every single of the factor results, which are presented in Table 4 . High reliability values can be observed, the academic factor $(\alpha=0.922)$ being the highest, this is possibly due to this factor having nine statements, while the physical factor $(\alpha=0.790)$ is the one with the lowest reliability due to it only having four statements, although if item F22 (cost affordability) were to be removed the reliability of the instrument would rise to $\alpha=0.863$. Due to this, it has been opted to be kept within the instrument. In general, the instrument is very reliable $(\alpha=0.956)$

Table 4

Internal Consistency Values (Cronbach's Alpha)

\begin{tabular}{ll}
\hline Scale & Cronbach' $\alpha$ \\
\hline Complete & 0.956 \\
Spiritual & 0.853 \\
Academic & 0.922 \\
Social & 0.921 \\
Physical & 0.790 \\
\hline
\end{tabular}




\section{Construct Validation with Structural Equations}

The structural equations model from the Amos 22.0 Software was utilized to evaluate the university image validation construct.

The database in SPSS had various missing data; the database was purged, utilizing the arithmetic mean in each of the indicators.

The model diagram was constructed, in which both the dimensions and indicators of the image construct are shown. In this model, the relationships between relations and dimensions were established.

Huerta Wong and Espinoza Montiel (2012) noted that, in order to evaluate the model, the goodness fit index (GFI) can be used (see Table 5). The most used criteria have been selected from the list, which include the following: chi-square $\left(X^{2}\right)$, chi-square ratio/degrees of freedom, comparative fit index (CFI), GFI and root mean square error of approximation (RMSEA).

The proposed model for the university image construct can be observed in Figure 1, it consists of 25 indicators. While solving the model, no problems were detected, due to the indicator's corresponding variances were found to be positive and the standardized coefficients were less than 1. Examining the regression coefficients, it was found that each of them was significant, due to them having less or equal $p$ levels of 0.001 .

To begin the validation process of the construct, first the normality of the image construct was revised by utilizing the Mahalanobis distances. The data were reduced from 334 to 175 . The standardized regression coefficients were revised and were adjusted to 1. Later, the residual moments were revised as well as the adjustment of indexes, resulting in a model with 14 statements. The university image model presented good index adjustments, according to selected indexes as criteria $\left(X^{2}=85,253, p=0.119, X^{2} / \mathrm{gl}=1.201, \mathrm{CFI}=0.987\right.$, $\mathrm{NFI}=0.931$, RMSEA $=0.034$ ).

In reference to the criteria in Table 5, the validation of the latent variable university image is very good, due to all of the selected indexes were achieved.

Table 5

Goodness of Fit Statistics

\begin{tabular}{lll}
\hline Statistics & Abreviation & Criteria \\
\hline Absolute adaptation & & \\
Chi-square & $X^{2}$ & Significance $>0.05$ \\
Chi-square ratio/degrees of freedom & $X^{2} / \mathrm{gl}$ & Less than 3 \\
$\begin{array}{l}\text { Comparative adaptation } \\
\text { Confimatory fit index of comparative adaptation }\end{array}$ & CFI & $\geq 0.95$ \\
Tucker-Lewis index & TLI & $\geq 0.95$ \\
Normalized fit index & NFI & $\geq 0.95$ \\
Parsimony adaptation & & \\
Correction by parsimony & PNFI & Next to 1 \\
Other & & \\
Goodness fit index adaptation & GFI & $\geq 0.90$ \\
Adjusted goodness fit index & AGFI & $\geq 0.95$ \\
Root mean square residual avarege & RMR & Next to 0 \\
Root mean square error approximation & RMSEA & $<0.10$ \\
\hline
\end{tabular}




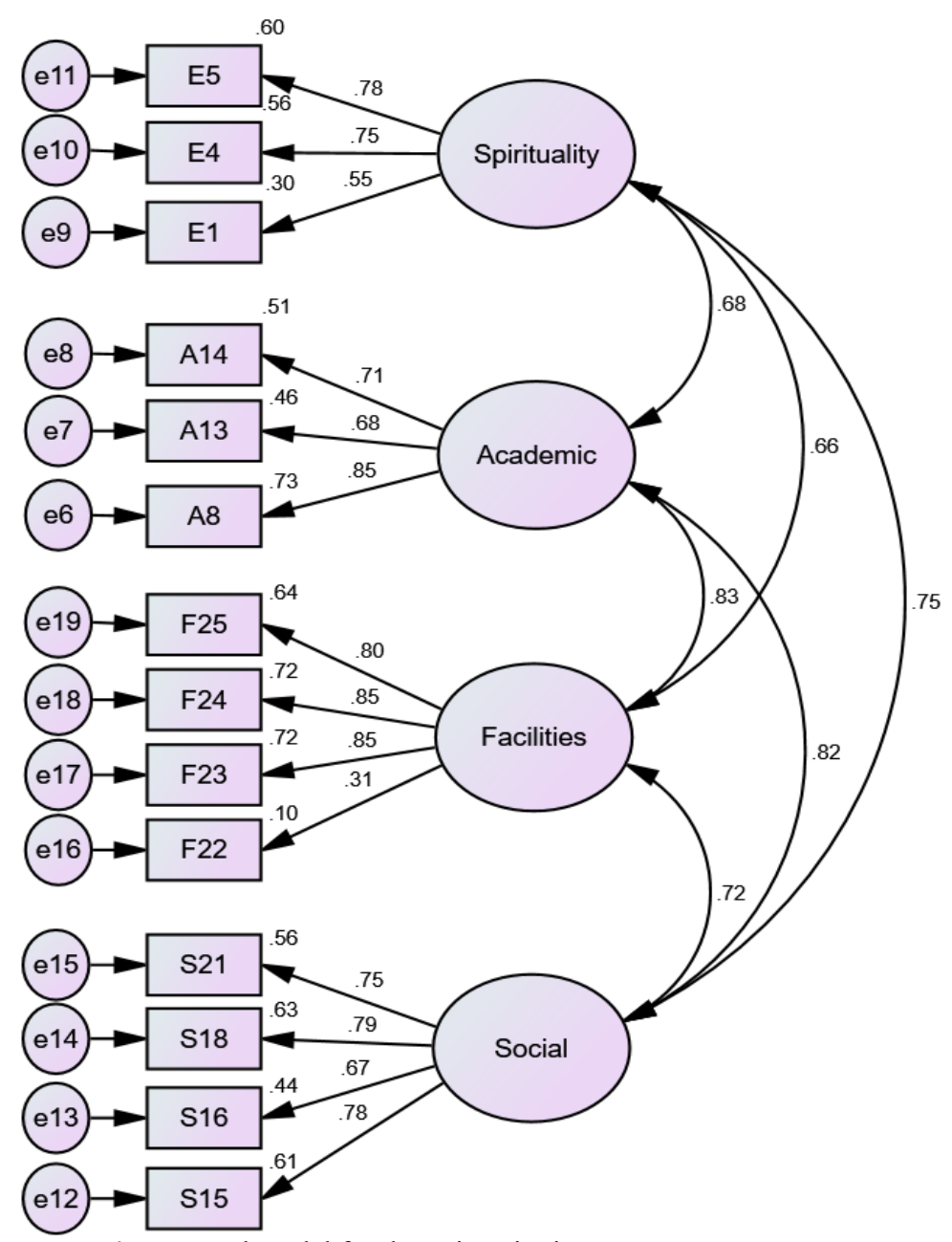

Figure 1. Proposed model for the university image construct.

\section{Conclusion}

The purpose of this study was the creation of an instrument to measure the image of universities, also with the intent that other institutions can utilize this instrument to know the perception that the different communities have towards them.

With the help of the statistic techniques such as factorial analysis and structural equations, the study came to the following conclusions:

(1) For the image instrument construct validation of university institutions, items whose theoretic bases are backed by previous studies were used;

(2) The factor analysis showed that the universities' institutional image could be dimensioned into four factors: spiritual, academic, social and physical;

(3) The instrument has construct validation and a high reliability;

(4) While doing the confirmatory validation of the construct with structural equations, the validation of the instrument was confirmed, mainly because all the selected criteria were achieved. 
This study had one limitation, namely, the usage of a denominational university with unique characteristics in terms of the spiritual factor. For future studies, it is recommended replicating this instrument in both public and private universities. In addition, other communities can be studied, such as parents, teachers, businessmen, other institutional authorities, etc..

\section{References}

Arranz Valles, J. C. (2003). Comunicación en las organizaciones. Barcelona: Océano.

Baptista Rodrigues, A. A. (2012). El desarrollo de una estrategia educativa para las instituciones de enseñanza superior en tiempos de incertidumbre. Instituto Superior Autónomo de Estudos Politécnicos (IPA). Retrieved from http://www.educaweb.com/noticia/2012/03/12/desarrollo-estrategia-educativa-instituciones-ensenanza-superior-tiempos-ince rtidumbre-5337/

Chaves, N. (2010). La imagen corporativa: Teoría y práctica de la identificación institucional (3rd ed.). México: GG Diseño.

Etzkowitz, H., Webster, A., Gebhardt, C., \& Terra, B. R. C. (2000). The future of the university and the university of the future: Evolution of ivory tower to entrepreneurial paradigm. Research Policy, 29(2), 313-330. doi: 10.1016S0048-7333(99)00069-4

Guerra, V., \& de Arends, P. (2008). Medición de la imagen institucional de un postgrado universitario. Ingeniería Industrial. Actualidad y Nuevas Tendencias, 1(1), 10-20.

Hair, J., Anderson, R., Tatham, R., \& Black, W. (2007). Análisis multivariante (5th ed.). Madrid: Prentice Hall Iberia.

Huerta Wong, J. E., \& Espinoza Montiel, R. (2012). Introducción a los modelos de ecuaciones estructurales con AMOS: Aplicaciones con la EMOVI. Retrieved from http://www.ceey.org.mx/site/files/ecuacionesestruc_jehw_0.pdf

Instituto Nacional de Estadística y Geografía (National Institute of Science and Geography). (2011). México en cifras. Retrieved from http://www3.inegi.org.mx/sistemas/Movil/MexicoCifras/mexicoCifras.aspx?em=19038\&i=e

Kotler, P., \& Fox, K. F. (1995). Strategic marketing for educational institutions (2nd ed.). New York, NY: Prentice Hall.

Meza, F., \& Meza, R. (2007). Calidad de la planta física y calidad de la imagen en la Universidad de Navojoa. Memorias, 8(1), 67-73.

Pintado Pasapera, E. A. (2015). Cultura corporativa, clima laboral e imagen institucional de las instituciones educativas publicas de educacion secundaria del Distrito de Carmen de las Legua Reynoso, Callao (Tesis de Maestría). Callao, Perú: Universidad nacional de Callao.

Romero, E. (2007). La juventud es uno de los principales valores de esta universidad. Mundo Empresarial Europeo, 95.

Sanz de la Tajada, L. A. (2003). Cómo comunicar la imagen de empresa. MK: Marketing + Ventas, 179, 43-47.

Vicerrectoría Académica de la Universidad de Montemorelos (Academic Vice-Rectorate of the University of Montemorelos). (2013). Compromiso educativo 2011-2016. Montemorelos, Nuevo León, México: Universidad de Montemorelos.

White, E. G. (1971). Consejos para los maestros. Miami, FL: Asociación Publicadora Interamericana.

White, E. G. (1975). La educación cristiana. Miami, FL: Asociación Publicadora Interamericana. 


\section{Appendix A}

The University of Montemorelos

Perceived Image of the UM

Directions: Evaluate the image perception that you have towards the University of Montemorelos utilizing the following scale: 1 = Poor (a); 2 = Bad (a); 3 = Regular; $4=\operatorname{Good}(a) ; 5=$ Excellent.

\begin{tabular}{|c|c|c|c|c|c|}
\hline Statements & 1 & 2 & 3 & 4 & 5 \\
\hline \multicolumn{6}{|l|}{ Religiousness } \\
\hline \multicolumn{6}{|l|}{ Christian philosophy } \\
\hline \multicolumn{6}{|l|}{ Moral principles } \\
\hline \multicolumn{6}{|l|}{ Conservative line } \\
\hline \multicolumn{6}{|l|}{ Goodness } \\
\hline \multicolumn{6}{|l|}{ Practical education } \\
\hline \multicolumn{6}{|l|}{ Innovative teachers } \\
\hline \multicolumn{6}{|l|}{ Academic quality } \\
\hline \multicolumn{6}{|l|}{ Lesson plan updates } \\
\hline \multicolumn{6}{|c|}{ Competitiveness of the graduates } \\
\hline \multicolumn{6}{|l|}{ Research orientation } \\
\hline \multicolumn{6}{|c|}{ Experienced teachers } \\
\hline \multicolumn{6}{|c|}{ Lesson plan exigency } \\
\hline \multicolumn{6}{|c|}{ Education technology } \\
\hline \multicolumn{6}{|c|}{ Centered in the student } \\
\hline \multicolumn{6}{|l|}{ Cultural diffusion } \\
\hline \multicolumn{6}{|l|}{ Student discipline } \\
\hline \multicolumn{6}{|l|}{ Student activity } \\
\hline \multicolumn{6}{|l|}{ Campus security } \\
\hline \multicolumn{6}{|l|}{ Community prestige } \\
\hline \multicolumn{6}{|c|}{ Relationships with the community } \\
\hline \multicolumn{6}{|l|}{ Cost affordability } \\
\hline \multicolumn{6}{|l|}{ Campus size } \\
\hline \multicolumn{6}{|l|}{ Campus cleanliness } \\
\hline \multicolumn{6}{|l|}{ Modern facilities } \\
\hline Institutional image & & & & & \\
\hline
\end{tabular}

